\title{
Winter climatic comparison between France and New Zealand: effects of frost damage on populations of Leptospermum scoparium JR et G Forst grown at three locations in France
}

\author{
W Harris 1 , L Decourtye 2 \\ 1 Botany Institute DSIR Land Resources, Private Bag, Christchurch, New Zealand; \\ 2 INRA, Station d'Amélioration des Espèces Fruitières et Ornementales, 49070 Beaucouzé, France
}

(Received 15 February 1991; accepted 24 September 1991)

\begin{abstract}
Summary - Ornamental cultivars of Leptospermum scoparium, a species indigenous to New Zealand and Australia, have restricted horticultural use in France because of limited cold hardiness. In New Zealand wild populations of the species are widely distributed across 14 degrees of latitude and from the coast to $1400 \mathrm{~m}$ above sea level. Existing ornamental cultivars appear to have been derived from plants collected at lower latitude and low altitude sites. Populations representing the latitudinal and altitudinal range of $L$ scoparium (fig 1$)$ in New Zealand were grown at Angers, Landerneau and Frejus to test their adaptation to a range of habitats in France. Plants were set out in the field before the $1987 / 1988$ winter at all sites and also in spring 1988 at Angers. Plant death in the first year was attributed to drought stress at transplanting, frost in the 1987/1988 winter, and high soil pH in the range 7-8 at Fréjus which caused widespread chlorosis. Because of this chlorosis, detailed observations on cold damage were made for only the Angers and Landerneau plantings after the 1988/1989 winter (tables I, II). During this winter the lowest screen minimum temperature at Angers was $-5.6^{\circ} \mathrm{C}\left(-9.1^{\circ} \mathrm{C}\right.$ grass minimum) and at Landerneau $-3.5^{\circ} \mathrm{C}$ (fig 2). Cold damage was much greater at Landerneau suggesting the climate of Angers produced more effective cold hardening. At the evaluation sites in France cold damage was significant for low latitude coastal populations, and negligible for South Island montane populations of $L$ scoparium (figs 4,5). Spring bud movement at Angers was most advanced for high latitude populations, but was retarded for montane populations (fig 6). These results are discussed with reference to temperature and day length regulation of cold hardiness. Comparison of the temperature regimes of the colder zones of the South Island, New Zealand, and the temperate zones of France (figs $3 a, 3 b, 3 c$ ) show these to be sufficiently similar to envisage the increased use of New Zealand plants in the horticulture of western Europe. To enable this increased use, other factors beside temperature limitations such as soil permeability and soil acidity will have to be considered.
\end{abstract}

ornamentals / cold hardiness / adaptation

Résumé - Observations du comportement hivernal de populations de Leptospermum scoparium (JR et G Forst) (Myrtacées), au regard de la climatologie comparée de la Nouvelle-Zélande et de la France. L'utilisation en France des cultivars ornementaux de Leptospermum scoparium, Myrtacée originaire de Nouvelle-Zélande, est limitée par leur sensibilité au froid. Dans son pays d'origine, l'aire de répartition de l'espèce s'étend sur 14 degrés de latitude et va des régions côtières à des altitudes pouvant atteindre $1400 \mathrm{~m}$. Les cultivars ornementaux actuels proviennent de plantes collectées à des latitudes faibles et en altitude basse. Des populations de semis, représentatives de l'ensemble de l'aire de distribution de L scoparium (fig 1) ont été implantées dans 3 zones climatiques françaises, à savoir, Angers, Landerneau et Fréjus. Ce matériel a été mis en place à l'automne 1987 pour les trois sites avec une répétition au printemps 1988 à Angers. La mortalité des plants de la première saison de végétation peut être rapportée en partie à un échec immédiat de transplantation entrainant un dessèchement des plantes, en partie à des dégâts de froid au cours de l'hiver 1987/1988. Des pH élevés (7-8) dans la parcelle de Fréjus ont provoqué une chlorose généralisée ne permettant pas une évaluation ultérieure des dégâts de froid. Ceux-ci ont fait l'objet d'observations précises à Angers et à Landerneau après l'hiver 1988/1989 (tableaux I et II). Au cours de cette période, le minimum absolu sous abri a été de $-5,6^{\circ} \mathrm{C}$ à Angers $\left(-9,1^{\circ} \mathrm{C}\right.$ au sol) et de $-3,5^{\circ} \mathrm{C}$ à Landerneau (fig 2). Cependant, c'est à Landerneau que les dégâts ont été les plus marqués, suggérant un meilleur endurcissement du matériel planté à Angers. Ces résultats font apparaître des dommages importants pour les populations des basses altitudes, tandis que les origines d'altitude de l'île du Sud sont pratiquement indemnes (fig 4, 5). Au printemps, le débourrement des prove- 
nances d'altitude est retardé par rapport aux provenances côtières, mais les provenances méridionales sont en avance sur les provenances septentrionales (fig 6). Ces résultats sont discutés en relation avec l'effet des températures et de la longueur du jour sur l'endurcissement au froid. L'étude des régimes de température fait apparaître des similitudes suffisantes, entre les zones les plus froides de l'ile du Sud et les régions tempérées de la France (figs $3 a$, 3b, 3c), pour envisager une utilisation accrue de la flore de Nouvelle-Zélande dans l'horticulture de l'Europe de l'Ouest. Au-delà des contraintes de température, d'autres facteurs limitants pourront apparaître, comme la perméabilité des sols ou leur degré d'alcalinité.

ligneux ornemental / résistance au froid / adaptation

\section{INTRODUCTION}

The genus Leptospermum includes 79 species (Thompson 1989) which occur from the Malay Peninsula, through Australia to New Zealand. All but a few of the species are endemic to Australia, and the only species native in New Zealand, Leptospermum scoparium, also occurs naturally in the Australian states of New South Wales, Victoria and Tasmania. Of the species of Leptospermum it is $L$ scoparium that has received most attention as an ornamental shrub. It was introduced to the British Isles soon after it was collected during Cook's first voyage of discovery to New Zealand in 1769-1770 (Brooker et al, 1988). Since that time it has been grown outdoors as an ornamental shrub in the milder south west regions of the British Isles, but in other parts of the British Isles the species is likely to be damaged or killed by winter cold if it is not given adequate shelter (Bean, 1973). Even in south west England, low winter temperatures, such as those which occurred in January 1987, can severely damage and may even kill the species in some years.

In New Zealand, L scoparium is widespread occurring in the North, South and Stewart Islands which lie between latitudes $34^{\circ}-48^{\circ} \mathrm{S}$, and from the coast to altitudes of $\approx 1400 \mathrm{~m}$. Natural populations of the species in New Zealand mostly have white flowers, but plants with varying degrees of pink coloration of the petals occur frequently throughout the country, especially in the far north of the North Island where a pink flowered variety, incanum, is recognized (Allan, 1961).

The origin of ornamental cultivars of $L$ scoparium (Lammerts, 1945; Metcalf, 1987) suggests that they derive from plants collected from localities not subjected to temperatures as low as those experienced by population of the species at the extreme of its range at higher altitude inland locations in the South Island, New Zealand. Consequently there is the possibility that geno- types with greater cold hardiness than those previously introduced into Europe may occur. If these could be identified they would provide parent plants from which to breed ornamental cultivars of $L$ scoparium better suited for outdoor use in Europe.

Other factors beside latitude of origin may influence the successful introduction of a species into areas outside its natural range. In particular, New Zealand has for the most part an even maritime climate, without extremes of heat, cold and drought. It is not subjected to continental climatic influences which have a marked effect on regional climates in Europe. Edaphic effects can also determine whether a species can be successfully introduced outside its natural range, but this poses less of a limitation because the intensive cultivation practices possible in gardens can modify conditions to suit a species' soil requirements.

Connor (1985) reviewing research on the biosystematics of higher plants in New Zealand concluded that experimental studies needed for the recognition of ecotypes in New Zealand were few. Work carried out on $L$ scoparium indicates that it is versatile in its response to different environments, and that this versatility is determined to some extent by ecotypic differentiation (Cook et al, 1980; Lee et al, 1983; Yin et al, 1984). Studies on freezing resistance of detached shoots of $L$ scoparium suggest that it can resist damage up to a temperature range between $-5^{\circ} \mathrm{C}$ to $-8^{\circ} \mathrm{C}$ (Sakai and Wardle, 1978; Bannister, 1986). Bannister (1986) found that plants originating from locations with markedly different temperature regimes differed little in their response to freezing and concluded that little ecotypic differentiation with regard to frost resistance occurs in the species.

Sakai and Wardle (1978) indicated differences in freezing resistance of plants of the New Zealand species Phyllocladus alpinus, Weinmannia racemosa and Nothofagus solandri obtained from lowland and montane sites. They also made a comparison between a cultivated plant of 
L scoparium grown in Japan and a wild plant from a lowland site in Westland, South Island, New Zealand. The Westland plant showed a freezing resistance of $-7^{\circ} \mathrm{C}$, and the plant from Japan $-5^{\circ} \mathrm{C}$. It is not indicated from which part of New Zealand the cultivated plant in Japan originated. Warrington and Stanley (1987) subjected whole plants of $L$ scoparium to freezing in a controlled climate chamber at four seasons. Seasonal hardiness of the species differed with maximum hardiness in winter when freezing damage occurred at $-4^{\circ} \mathrm{C}$ and plant death at $-8^{\circ} \mathrm{C}$.

This paper reports on observations on winter cold damage to populations of Leptospermum scoparium grown at three locations in France. Particular emphasis was placed on evaluation of populations obtained from higher inland locations of the South Island New Zealand where it is more likely that natural selection for freezing resistance has occurred.

\section{MATERIALS AND METHODS}

\section{Origin of populations}

Seeds to raise plants of Leptospermum scoparium for observation were collected either from plants growing in wild localities or from plants growing in an experimental garden at Botany Institute, DSIR Land Resources, Lincoln, near Christchurch, New Zealand. The locations of the 37 populations studied are plotted in figure 1 to show their latitudinal origin. Seed collected from the wild included 9 populations collected by $W$ Harris and 6 collected by L Decourtye (table I). In order to reduce the consequences of intercrossing, seed from plants in the experimental garden at Lincoln was obtained from the middle of blocks of plants from the same population site. Details of the 22 populations obtained in this way are given in table II.

In both tables I and II, populations are listed in order of increasing latitude of origin. Altitude and distance from the coast for the population sites are classified as being coastal $(C)$, intermediate $(I)$ or montane $(M)$. The montane populations include those from inland South Island sites at altitudes above $500 \mathrm{~m}$, the coastal populations are from sites near the sea, while the intermediate populations are from a diverse range of sites neither coastal nor montane.

\section{Evaluation sites}

After raising under a common nursery procedure, oneyear-old seedlings were planted at 3 evaluation sites.

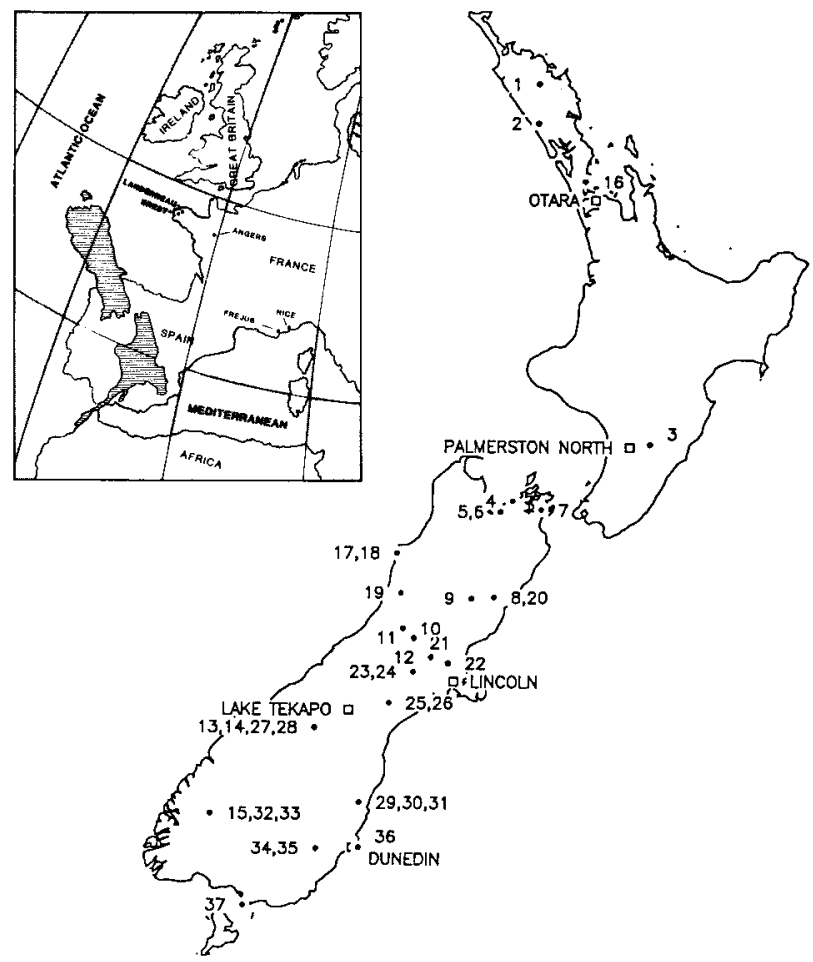

Fig 1. Map showing sites of origin of New Zealand populations of Leptospermum scoparium and evaluation sites and climate stations in New Zealand referred to. Plotted numbers relate to the population numbers in tables I and II. The inset map shows the relative latitudinal situation of the evaluation sites in France.

\section{Angers}

At the Station d' Amélioration des Espèces Fruitières et Ornementales, domaine de Bois l' Abbé, Beaucouzé near Angers $\left(47^{\circ} 28^{\prime} \mathrm{N} 00^{\circ} 36^{\prime} \mathrm{W}\right)$. It has an altitude between $35-40 \mathrm{~m}$ with a slope of $4.3 \%$ facing west. The meteorological station is $\approx 200 \mathrm{~m}$ from the site on a similar aspect. Two plantings were made at this site; in autumn 1987 on 28 October and in spring 1988 on 28 March. Each population was planted as a row in each of the autumn and spring plantings. Most populations had 20 plants at each planting, but overall, fewer plants were available for the spring planting.

\section{Landerneau}

At the Station d' Amélioration de la Pomme de Terre et des Plantes à Bulbes, Ploudaniel, near Landerneau $\left(48^{\circ} 50^{\prime} \mathrm{N} 04^{\circ} 50^{\circ} \mathrm{W}\right)$. It is situated on level ground in a small depression surrounded by trees on 3 sides at an altitude of $\approx 80 \mathrm{~m}$. The meteorological station is about $500 \mathrm{~m}$ from the site. The planting was made on 23 April 1987. Most populations were represented by 20 plants at this site divided into rows of 10 plants in 2 replicate blocks. 
Table I. Observations for Leptospermum scoparium populations raised from seed collected from the wild in New Zealand.

Number and
population site

\section{$\%$ dead plants}

A $\quad L \quad F$

A Mean cold damage

(1)

(2)

$\begin{array}{llll}3.00 & 1.33 & 3.00 & 1.73 \\ 2.33 & 0.51 & 2.58 & 2.11\end{array}$

1. L Waipareheka, Ngawha, Kaikohe

\section{Dargaville}

I 21.1

30.0

43.6

36.8

$-$

5.0

0.0

1.51

0.11

0.58

2.75

4. Red Hills,

Whangamoa, Nelson

c

24.3

10.0

0.0

1.96

0.25

3.00

2.39

5. Maitai Valley, Nelson

C $\quad 27.8$

5.0

2.6

0.81

0.15

0.95

2.65

6. Maitai Valley, Nelson

C $\quad 7.5$

0.0

2.6

0.73

0.0

0.55

2.89

7. Karaka Point, Picton

C $\quad 10.3$

0.0

15.4

2.73

0.58

3.05

2.34

8. Whalesback

North Canterbury

9. Jacks Pass, Hamner

15.0

0.0

2.6

0.53

0.00

0.00

2.86

M $\quad 10.5$

5.0

13.2

0.26

0.00

0.21

2.21

10. Arthurs Pass

M $\quad 0.0$

0.0

7.7

0.34

0.00

0.00

2.61

11. University Biological Station, Cass

12. Viewhill near Oxford

M $\quad 0.0$

10.0

0.48

$0.00 \quad 0.00$

1.90

$0.0 \quad 0.0$

0.57

0.00

0.10

2.43

13. Lake Ohau Canterbury

14. Lake Ohau Canterbury

20.0

0.0

0.0

0.21

0.00

0.10

2.54

10.0

0.08

0.00

0.27

2.80

$0.0 \quad 10.3$

0.34

0.00

0.20

2.32

Southland

Evaluation sites $: A=$ Angers; $L=$ Landerneau; $F=$ Fréjus. Localities: $C=$ coastal; $I=$ intermediate; $M=$ montane. Population not planted at site. (1) Obs. erver W Harris; (2) Observer L Decourtye.

\section{Fréjus}

At the Station d' Amélioration des Plantes Florales, Domaine de la Gaudine, Fréjus $\left(43^{\circ} 40^{\prime} \mathrm{N} 06^{\circ} 40^{\prime} \mathrm{W}\right)$. It has an altitude of $\approx 4 \mathrm{~m}$ on level ground. The meterological station is $200 \mathrm{~m}$ from the site on similar terrain. The soil results from a recent catastrophic flood providing sediment of uneven composition which has covered the original soil, with $\mathrm{pH}$ varying from 7.0-8.2. The planting took place in June 1987. Most of the populations were represented by 40 plants split into rows of 20 plants for each population in 2 replicate blocks.

\section{Observations}

The overall objective of the project was to select those genotypes of Leptospermum which would provide the best plants for use as ornamental specimens or as hedge plants. It was anticipated that the 3 evaluation sites would provide a screening for the adaptation of the Leptospermum populations to 3 climatic regions in France and in particular resistance to freezing temperatures. Notes were made on the form, vigour, coloration and flowering characteristics of the plants in the course of their growth in order to make a decision on which individual plants should be retained, propagated 
Table II. Observation for Leptospermum scoparium populations raised from seed collected from experimental planting at Lincoln, New Zealand.

Number and

population site
$\%$ dead plants

A $L \quad F$

\begin{tabular}{lll}
\multicolumn{3}{c}{ Mean cold damage } \\
$A$ & $A$ & $L$ \\
(1) & (2) & (3)
\end{tabular}

Mean

bud

movement

16. Scenic Reserve

Albany, Auckland

C 29.4

17. Charleston, Westland

18. Charleston, Westland C

19. Nelson Creek, Westland I

20. Whalesback

North Canterbury

I

21. Cragieburn Forest Park,

Canterbury

$M$

22. Eyrewell Scenic Reserve,

Canterbury

$\begin{array}{lll}2.7 & 0.0 & 11.6\end{array}$

2.9

0.0

30.0

22.2

0.0

0.0

0.0

2.5

0.48

4.25

2.50

3.47

1.58

1.43

0.00

0.72

2.20

1.00

0.00

2.00

2.96

0.71

0.21

0.40

2.36

Range, Canterbury

21.6

7.5

$0.0 \quad 0.0$

0.84

0.11

0.50

27. Lake Ohau, Canterbury M

23.2

$0.0 \quad 10.0$

0.70

0.00

0.15

0.41

0.00

0.00

2.85

29. Herbert Forest

Waianakarua, Otago

$1-36.8$

30. Waianakarua, Otago

31. Waianakarua, Otago

32. Lake Te Anau,

Southland

M

33. Lake Te Anau,

Southland

M

34. Waipori, Lawrence

Otago

14.9

$0.0 \quad 12.5$

0.46

0.08

1.10

3.16

$\begin{array}{llll}\text { C } & 0.0 & 10.0 & 2.5\end{array}$

0.55

0.00

0.94

3.55

1.18

0.00

0.56

3.41

35. Waipori, Lawrence

Otago

18.3

C $\quad 11.1$

$0.52 \quad 0.00$

0.40

2.63

Otago Peninsula

37. Bluff Hill

Southland

C $\quad 10.5$
0.0

7.5

0.0

2.5

$\begin{array}{lll}0.75 & 0.00 & 0.16\end{array}$

2.56

$0.0 \quad 0.0$

$0.53 \quad 0.03$

0.15

1.88

0.15

2.70

3.13

$\begin{array}{lll}0.79 & 0.00 \quad 1.35\end{array}$

2.79
$0.30 \quad 0.00$ 
and evaluated further as horticultural plants. Results relevant to the response of the populations to freezing temperatures have been reported in this paper.

\section{Angers}

On 26 May 1988 a record was made of living and dead plants in both the autumn and spring plantings and a note was made of those populations showing cold damage.

On 9 March 1989 cold damage to the plants was scored by $L$ Decourtye on a $0-5$ scale as follows:

$0)$, no visible damage to shoots;

1), slight damage to shoots;

2), dead leaves and twigs on 1/4 of branches;

3), dead leaves and twigs on 1/2 of branches;

4), dead leaves and twigs on 3/4 of branches;

5), severe damage to plant, with most or all branches having dead leaves and twigs.

On 2-3 May 1989 the plants were scored by W Harris on a $0-5$ scale as follows:

0), no visible damage to shoots;

1), one to 5 shoot tips damaged, but without damage to mature shoot tissue;

2), six or more shoot tips damaged, but without damage to mature shoot tissue;

3), mature leaf tissue damaged on 1-3 branches;

4), mature leaf tissue damaged on more than 3 branches;

5), severe damage to plant, with most or all branches with a large amount of dead leaf tissue.

On 2-3 May 1989, the extent of bud expansion and shoot elongation was scored on a $0-5$ scale by $W$ Harris with $0=$ buds mostly dormant and no or little shoot extension and $5=$ extensive leaf expansion and shoot elongation. This score involved an overall assessment of each plant as shoots on different positions on the plant showed different growth activity. The purpose was to determine if there were population differences in growth periodicity at a time when rising spring temperature was activating growth.

\section{Landerneau}

On 15 September 1987 and again on 5 October 1988 a note was made on the appearance of the plants and the numbers of dead plants.

In March 1989 cold damage to plants was recorded by $L$ Decourtye using the same scale as applied to the plants at Angers. The site was visited briefly by $L$ Decourtye and W Harris on 21 July 1989 and a quick assessment made of the extent of cold damage to plants to confirm the observations made in March.

\section{Fréjus}

A general observation was made of this planting by $L$ Decourtye on 15 May 1988 on a population basis, but not on an individual plant basis. Many plants were observed to be chlorotic, probably as a response to areas of soil with $\mathrm{pH}$ near 8 . This phenomenon was reported on by $B$ Brocard, in a student project in the summer of 1987-1988, and the record of living and dead plants made during this study is given in tables 1 and II.

\section{RESULTS AND DISCUSSION}

Results are discussed in 5 parts: a), observations made on the environment of each evaluation site, particularly the winter temperature regimes, and comparison of these with temperature regimes of localities in New Zealand; b), the differences of cold damage between sites; c), within population variation of cold damage; d), the relationship between cold damage and the latitude and altitude of origin of populations; e), the relationship between spring bud movement and the latitude and altitude of origin of populations.

\section{Winter temperature regimes}

During the 1987/1988 winter the extreme minimum screen temperatures were; Angers $-6.5^{\circ} \mathrm{C}$ in December 1987, Landerneau $-2.4^{\circ} \mathrm{C}$ in March 1988 , and Fréjus $-3.4^{\circ} \mathrm{C}$ in March 1988.

During the $1988 / 1989$ winter at Fréjus the extreme minimum screen temperature was $-2.7^{\circ} \mathrm{C}$ in November 1988. As soil effects dominated plant performance at Fréjus, detailed observation on cold damage to plants was not made. Consequently details of the $1988 / 1989$ temperature regime at Fréjus are not presented.

The 1988/1989 winter temperature regimes for Angers and Landerneau are compared in figure 2 by plotting the mean daily temperatures for 10 day periods from September to April and the incidence of frost at screen level. During this winter the extreme minimum screen temperature at Angers was $-5.6^{\circ} \mathrm{C}$ on 23 November 1988 . On that day frost $10 \mathrm{~cm}$ above ground level was $-7.9^{\circ} \mathrm{C}$ and on the previous day $-9.1{ }^{\circ} \mathrm{C}$, similar to the most severe ground frost in the previous year of $-9.0^{\circ} \mathrm{C}$ which occurred on 10 December 1987. At Landerneau, the extreme minimum screen temperature for winter $1988 / 1989$ of $-3.5^{\circ} \mathrm{C}$ occurred on 27 November 1988. Ground level frost was not measured at Landerneau. Frosts were more frequent at Angers with 30 frost days compared to 16 at Landerneau.

Changes in mean daily temperatures for the period September-April 1988/89 show that while 


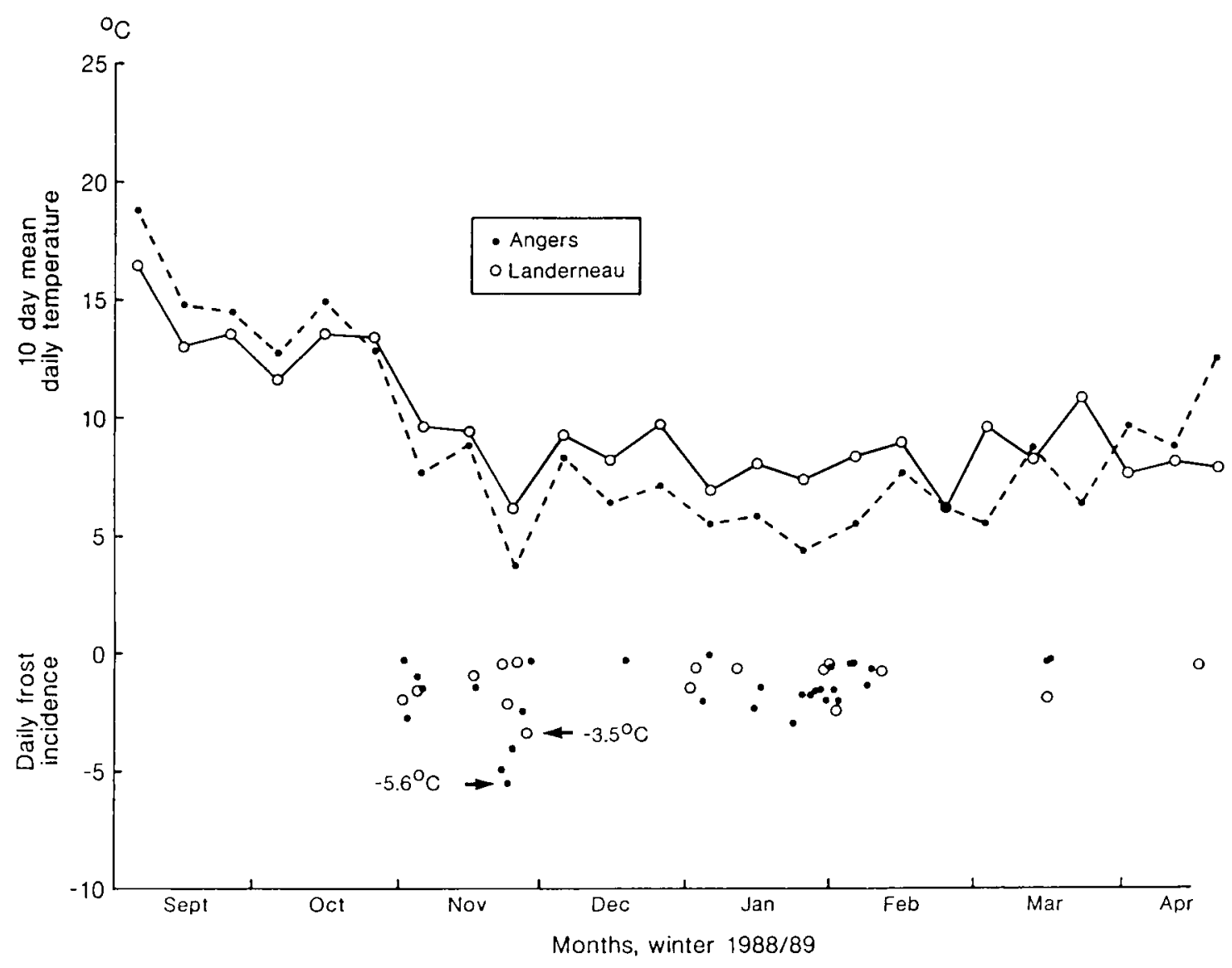

Fig 2. Comparison of temperature regimes at Angers and Landerneau in winter 1988/1989.

temperatures at Angers were higher than those at Landerneau in summer, the reverse was the case in winter when temperatures were lower at Angers. This is a consequence of maritime continental climate influences and may have 2 possible effects on the freezing tolerance of plants at the sites (Bossard and Cuisance, 1984). Higher summer temperatures at Angers compared to Landerneau may produce greater maturity of shrub tissue during the growing season. Milder temperatures at Landerneau from late October continuing into winter would more likely allow growth of frost tender tissue closer to the time when damaging frosts occur. Most probably the cold damage on which detailed observations were made in Spring 1989 resulted from the frosts that occurred at both Landerneau and Angers in late November 1988. As these 1988/89 frosts occurred earlier than the most severe frost at both Angers and Landerneau in winter 1987/ 88 less time was available for frost hardening to develop before damaging frosts in 1988/89 than in winter 1987/1988.

To consider to what extent the temperature regimes which caused the cold damage observed in spring 1989 were characteristic of the evaluation localities, and to allow comparison with the localities in New Zealand from which the evaluated population originated, mean monthly temperatures for 30 years or longer periods, and the coldest screen temperatures recorded for each month in those periods, are plotted in figures $3 a-c$. These data are obtained from published records of the official meterological services of France (Service Météorologique Métropolitain, Division Climatologie, Paris 1983) and the New Zealand Meteorological Service (1980). The official stations compared in France, Brest, Angers and Nice do not coincide exactly with the evaluation sites, but provide a general description of temperature regimes of the regions of these sites. The New Zealand sites selected allow comparison of temperature regimes within the distribution range of $L$ scoparium and provide reference to environments of previous evaluations of cold hardiness of the species.

Comparison of mean daily temperatures for Brest and Angers (fig $3 a$ ) indicates that the seasonal reversal of mean daily temperatures shown in 1988/89 is characteristic of the regions 

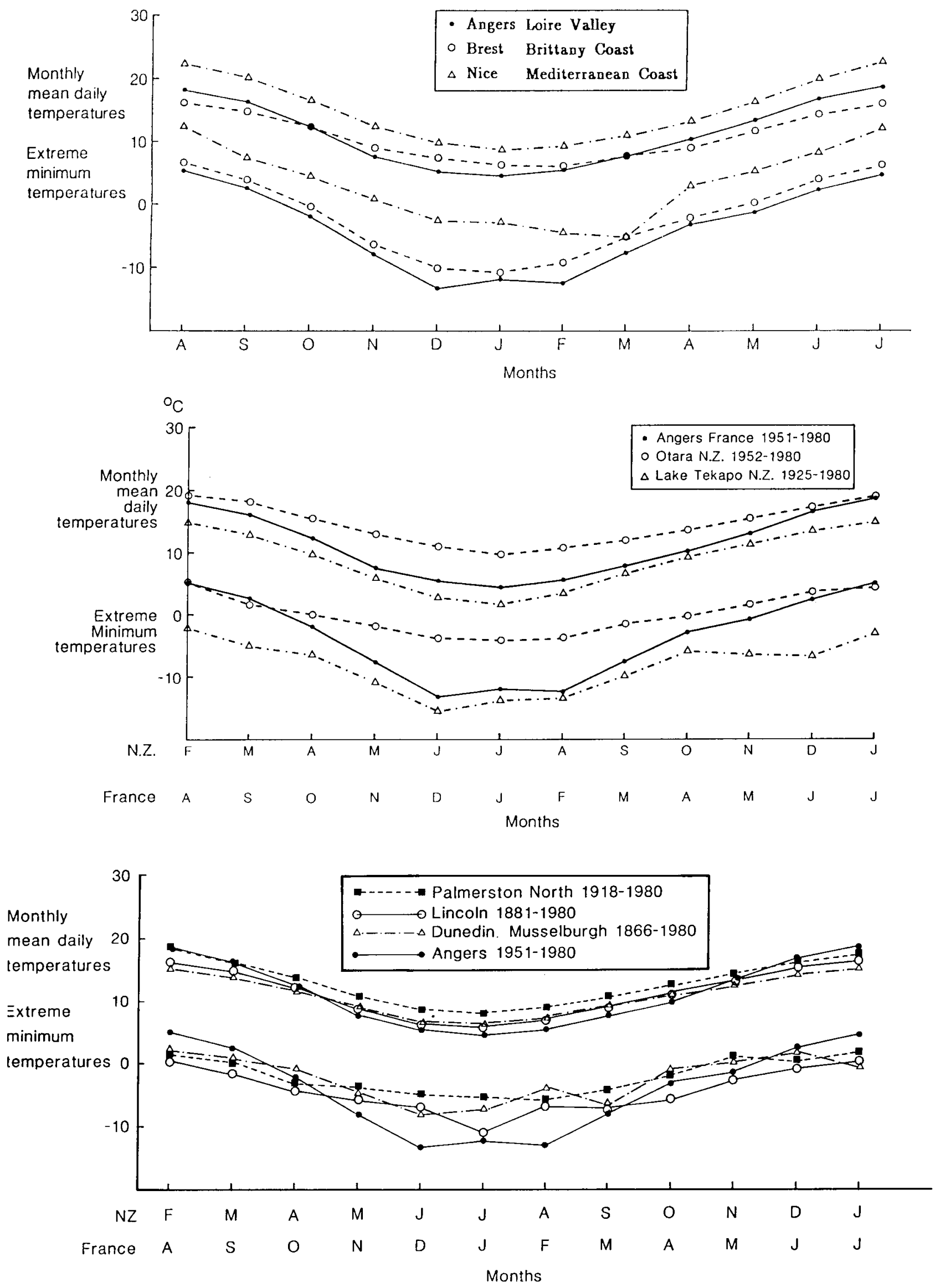

Fig 3. Comparison of long-term monthly mean daily screen temperatures and extreme minimum screen temperatures for each month of sites in New Zealand and France. a. Angers, Brest, Nice; b. Angers, Otara, Lake Tekapo; c. Angers, Palmerston North, Lincoln, Dunedin. 
of the Angers and Landerneau evaluation sites. Data for Nice indicate that for the region represented by the Fréjus site, mean daily temperatures are usually $2-4{ }^{\circ} \mathrm{C}$ higher than those at Brest and Angers at all months of the year.

The contrast between intensity of freezing temperatures at Nice compared with Brest and Angers is even greater. Nice shows a more protracted reduction of freezing temperatures as winter progresses, so that in November and December screen frosts at Brest and Angers have been 8$10^{\circ} \mathrm{C}$ lower than those experienced in Nice. Usually Brest experiences less severe frosts in winter than Angers because of the maritime influence including some effect of the Gulf Stream. However, infrequent but not exceptional flows of cold Arctic air can overwhelm latitudinal and maritime temperature influences and bring damaging freezing temperatures to coastal and other regions of France that do not usually experience severe freezing in winter (Bourgary, 1985). There was an episode of these events in the successive winters 1984/1985, 1985/1986 and 1986/87 when for the Angers INRA site the extreme minimum screen temperatures were $-14.6^{\circ},-15.0^{\circ}$ and $-18.0^{\circ} \mathrm{C}$ respectively, with the severest ground level frost of $-22^{\circ} \mathrm{C}$ recorded on 17 January 1987. All of these screen temperatures were lower than during the entire 30-year period from 1951 to 1980 for Angers shown in figure 3a. For the same series of winters, the extreme minimum screen temperatures at Landerneau were $-8^{\circ}$, $-8^{\circ}$ and $-9^{\circ} \mathrm{C}$ and at Fréjus $-8.5^{\circ},-6.6^{\circ}$ and $-6.9{ }^{\circ} \mathrm{C}$ respectively. All these temperatures were lower than any experienced during the two winters at the three sites where Leptospermum was evaluated.

New Zealand plant species characteristically are not tolerant of extreme cold (Allan, 1961; Sakai and Wardle, 1978), and for this reason the Leptospermum populations were not evaluated at sites within the greater area of France that has colder winters than Angers. Figure $3 b$ compares the temperature regime at Angers for the 19511980 period with long-term means and extreme minimum temperatures at contrasting sites in New Zealand. Otara, located within the narrow isthmus occupied by Auckland city, is at latitude $36^{\circ} 57^{\prime} \mathrm{S}$ longitude $174^{\circ} 52^{\prime} \mathrm{E}, 12 \mathrm{~m}$ above sea level. Lake Tekapo is located in an inland montane basin of the South Island at latitude 4401 longitude $170^{\circ} 28^{\prime} \mathrm{E}, 683$ metres above sea level. Mean daily temperatures at Otara vary from being $\approx 4{ }^{\circ} \mathrm{C}$ higher than those at Lake Tekapo in summer to being $\approx 8^{\circ} \mathrm{C}$ higher in winter. The seasonal amplitude of temperature at Angers of $14.1{ }^{\circ} \mathrm{C}$ is only a little higher than that at Lake Tekapo of $13.2^{\circ} \mathrm{C}$, and Angers is shown to have higher mean daily temperatures than Lake Tekapo for all months of the year.

Lake Tekapo has experienced screen frosts in all months of the year, and for the periods compared, experienced extreme minimum temperatures in winter $1-2{ }^{\circ} \mathrm{C}$ lower than those in Angers, the lowest recorded screen temperature at Lake Tekapo being $-15.6^{\circ} \mathrm{C}$. The lowest screen minimum recorded at Otara was $-4.1^{\circ} \mathrm{C}$, which indicates that the selection pressure on plants for avoidance of low temperature damage should be greater at Lake Tekapo, which lies within the area of the montane populations of Leptospermum scoparium, than at Otara, which is in the area of the northern coastal populations (tables I, II). While it is significant that the more usual winter temperature regime at Angers has similarities with that at Lake Tekapo, it is important to recognise that Lake Tekapo or other sites in New Zealand do not experience episodes of low temperature of a duration or intensity as those arising from the movement of polar air across a continental land mass.

Figure $3 c$ compares temperature regimes for Palmerston North (latitude $40^{\circ} 23^{\prime} \mathrm{S}$, longitude $175^{\circ} 37^{\prime} \mathrm{E}$, altitude $34 \mathrm{~m}$ ), Lincoln ( $43^{\circ} 54^{\prime} \mathrm{S}$, $\left.170^{\circ} 28^{\prime} \mathrm{E}, 11 \mathrm{~m}\right)$ and Musselburgh, Dunedin $\left(45^{\circ} 54^{\prime} \mathrm{S}, 170^{\circ} 31^{\prime} \mathrm{E}, 2 \mathrm{~m}\right.$ ) with Angers. These sites indicate the cold hardening regimes characteristic of the locations where Warrington and Stanley (1987) and Bannister (1986) carried out their freezing experiments in Palmerston North and Dunedin respectively, and Lincoln where observations on cold damage to Leptospermum have been made by $W$ Harris (unpublished observations). Seasonal levels of mean daily temperature for these New Zealand sites are intermediate between those for Otara and Lake Tekapo and they are similar to Angers, the main difference being the greater difference of winter and summer temperatures at Angers. This is similar to the comparison between Brest and Angers (fig 3a). It is suggested that the milder winter temperatures at Palmerston North and Dunedin would not have allowed full differential hardening of provenances of Leptospermum scoparium. This may explain why Warrington and Stanley (1987) and Bannister (1986) did not clearly show different freezing responses of Leptospermum scoparium of different origins, whereas differences were clearly shown at Angers and Landerneau (tables I, II). 
Also, cold damage to $L$ scoparium observed by W Harris of plants grown outdoors at Lincoln has not been as severe and has not shown differences between populations as clear as those observed at Angers and Landerneau. This is most likely explained by the lower minimum temperatures at Landerneau and Angers during the evaluation period, a difference also shown in the longterm minimum temperature extremes (fig $3 a, c$ ).

Inherent resistance of a population to cold damage could be expected to relate more directly to extreme minimum temperature than to the mean minimum temperatures occurring at the site of the population. This being the case populations from sites in New Zealand which have on average warmer temperatures than Lincoln could be expected to tolerate average winter minimum temperatures at Lincoln, and their sensitivity to cold is likely to be expressed only when unusually low minimum temperatures occur at Lincoln. Consequently sites in France, by having lower winter temperatures, provide more effective locations for the screening of cold tolerance of New Zealand $L$ scoparium populations than Lincoln.

\section{Site and observation differences of cold damage caused during winter 1988/89}

The percentage of plants that died in each population at the 3 evaluation sites are given in tables I and II. Most of these deaths occurred soon after the plants were planted at the evaluation sites. The most important cause of plant death was drought that affected the spring planting at Angers. Some plants were also killed by cold in the 1987/88 winter at both Angers and Landerneau. For example, the effects of this are shown by the high percentage of dead plants of the particularly cold sensitive populations 1 and 2 at Landerneau. At Fréjus it was indicated that plants differed in their response to high soil $\mathrm{pH}$, and where the effect of chlorosis was extreme this was a cause of death.

Mean scores for the damage resulting from cold during winter 1988/89 are given for all populations in tables I and II.

The regression, for the observations by $\mathrm{L} D e-$ courtye (tables I, II), of $y$ (cold damage score at Landerneau) $=0.585+1.55 x$ (cold damage score at Angers) $(P<0.001)$, indicates that the extent of cold damage shown at Landerneau was considerably greater than that at Angers.
The regression, comparing the 2 observations at Angers, $y$ (observation by $W$ Harris in May 1989 ) $=0.703+1.63 \times$ (observation by $L$ Decourtye in March 1989) indicates that there was good agreement $(P<0.001)$ between the observers, but that the extent of damage recorded was clearly greater at the later observation. This result may have been influenced by the different scales used, observer perception, or progression of damage over the 2 months between observations. The main difference of scale was the closer observation of shoot tip damage at the May observation. This gave a small damage score to populations recorded as not having any damage in March. The more likely effect of greater damage being shown in May than March is that damage plants had suffered became more apparent and some shoots had died between observations.

The previous consideration of the winter temperature regimes at the evaluation sites suggested that Landerneau had a regime that would result in shrub growth less hardy than that at Angers. This provides an explanation for the much greater cold damage that occurred at Landerneau with less severe frosts. Milder temperatures at Landerneau may also have allowed earlier expression of cold damage than was the case at Angers. This may have occurred in a way related to the change described between the March and May observation at Angers. However, the observation made at Landerneau in July 1989 when compared with the frequent observations at Angers showed that for cold susceptible plants, the extent of damage at Landerneau was very much greater even after any possible effect of differential timing of expression of cold damage was past.

While it appears that the temperature regime at Landerneau was not as effective in inducing cold hardening as that at Angers, many plants, especially those of higher altitude populations, were sufficiently hardy to avoid cold damage at this site. By comparison the Kaikohe (1) and Albany (16) populations in showing particular sensitivity to cold damage at Angers may have an inherent inability to harden. Both these sites, Kaikohe because of the influence of the warmth of the geothermal lake on whose shores the population is located, and Albany because of coastal, aspect or slope influence, may never experience severe frosts. If this is the case, selection pressure to develop an inherent seasonal cold hardening response will have been small. 


\section{Within population variation of cold damage}

The frequency distributions of damage scores (fig 4) for 3 populations show that even for the significantly damaged population from Kaikohe (1), which had some plants killed by cold in the first winter, there were also some plants in the population which were not or only slightly damaged. The same pattern applied to the coastal population from Picton (7) which is located near the middle of the latitudinal range of New Zealand. This population differs from the Kaikohe population mostly by having fewer plants which were more severely damaged or died. The population from the montane habitat of Te Anau (15) consisted mostly of plants that showed no damage, with a few showing minor shoot tip damage. The presence of a small proportion of cold tolerant individuals in the most cold sensitive populations of $L$ scoparium would provide a buffer for these populations against potentially severely damaging effects of atypical periods of cold in their wild locations.

\section{Relationship between cold damage and the latitudinal and altitudinal origin of populations}

Figure 5 plots the mean cold damage scores recorded by $W$ Harris at Angers of the populations of $L$ scoparium (tables I, II) against the latitude of origin of these populations. Coastal, intermediate and montane populations are distinguished in the plot, and for purposes of regression analysis are allocated values of 1,2 and 3 respectively. Although these values are referred to as 'altitude', they involve the influence of both altitude and distance from the coast.

The multiple regression: $y$ (cold damage score at Angers) $=11.2-0.222 x_{1}$ (latitude) $-0.337 x_{2}$ (altitude), is highly significant $(P<0.001)$. This indicates that cold damage to plants during the winter of 1988/89 increased with decreasing latitude and altitude of the site of origin of the population. Latitude accounted for $58 \%(P<0.001)$ and altitude $8 \%(P<0.01)$ of the variation. As all the montane populations were from latitudes higher than $42 \mathrm{~S}$, and as damage to all populations from latitudes higher than $42 \mathrm{~S}$ was comparatively minor shoot tip damage, freezing temperatures more severe than those experienced at Angers in winter 1988/89 would be required to more definitively test altitude related cold tolerance adaptation in $L$ scoparium. The relationship

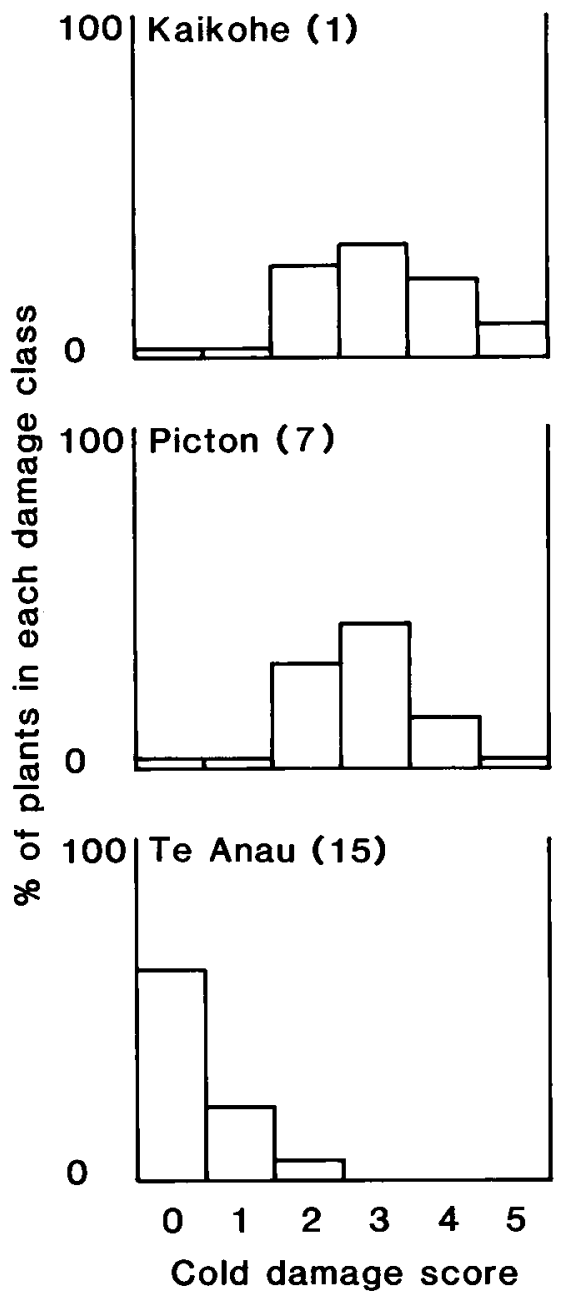

Fig 4. Frequency distribution of cold damage scores for 3 populations. Population numbers relate to details in table 1.

between latitude and altitude is in agreement with the hypothesis that natural selection has resulted in the genetic adaptation of $L$ scoparium populations to avoid damage from winter freezing temperatures which increase in frequency and intensity as latitude increases and according to the distance of the site of origin of a population from the coast and its altitude.

\section{Relationship between spring bud movement and latitudinal and altitudinal origin of popu- lations}

Figure 6 plots the mean bud movement scores recorded at Angers on May 2-3 1989 of the populations of $L$ scoparium against the latitude of origin of these populations. Bud movement is related to latitude and altitude of population origin through the very significant $(P<0.001)$ regression: 


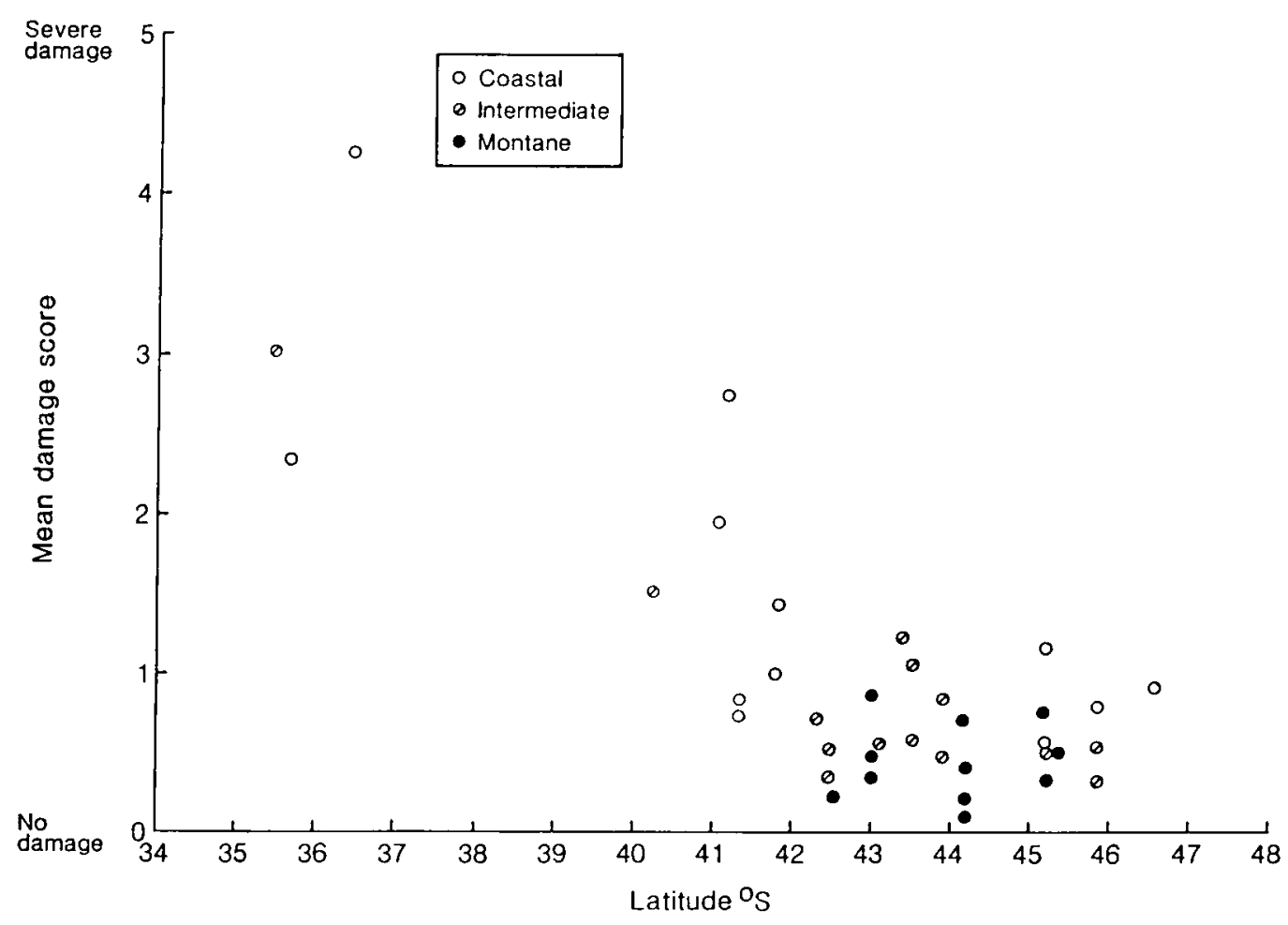

Fig 5. Relationship between cold damage score and latitude of origin of New Zealand populations of Leptospermum scoparium.

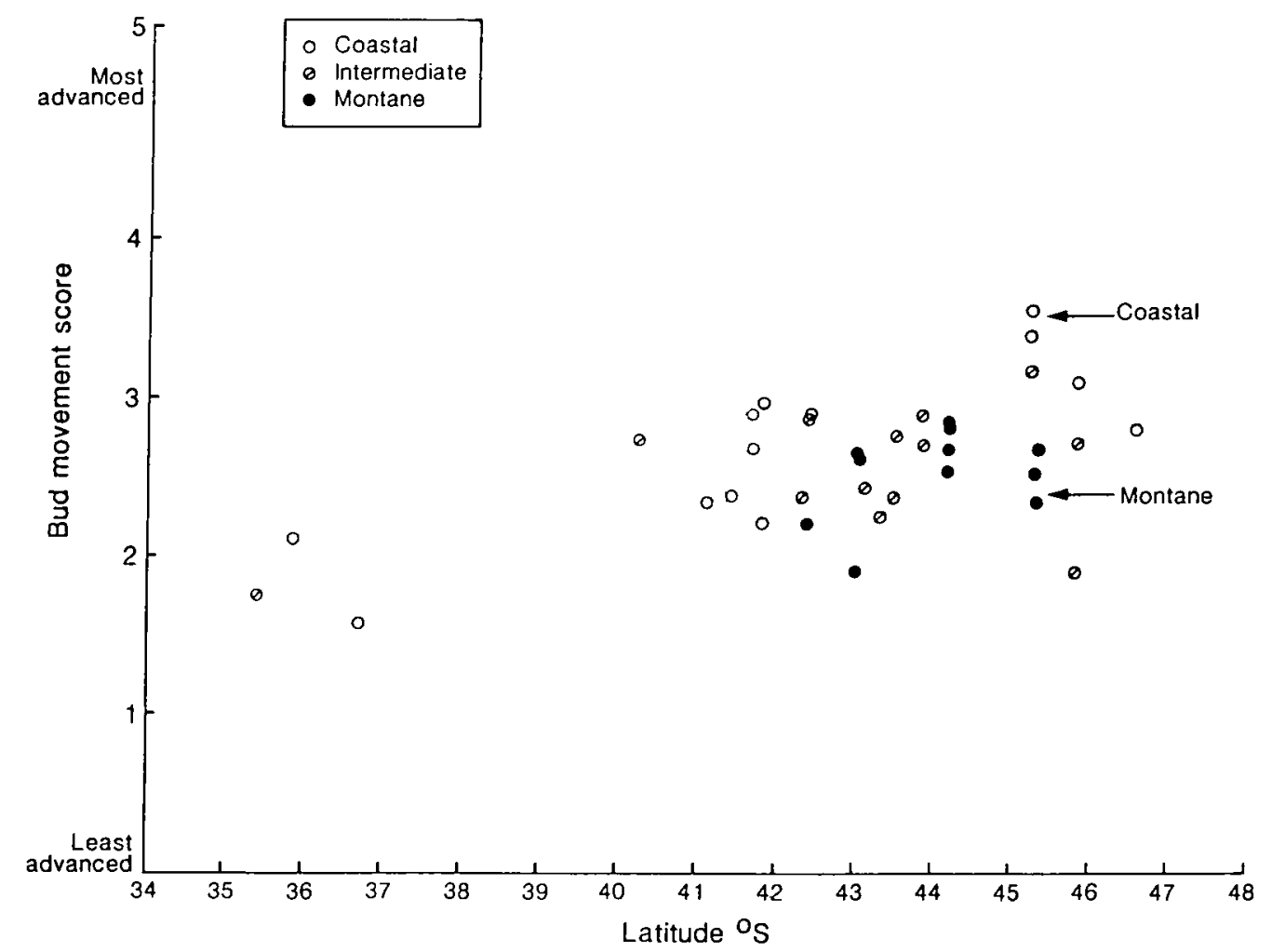

Fig 6. Relationship between bud movement score and latitude of origin of New Zealand populations of Leptospermum scoparium. 
$y$ (bud movement score) $=1.65+0.107 x_{1}$ (latitude) $-0.183 x_{2}$ (altitude).

This means that population bud movement is delayed by altitude of origin ( $9 \%$ of the variation, $P<0.02)$, but is more advanced with increasing latitude of origin $(31 \%$ of variation, $P<0.001)$. This indicates that the better frost resistance of the southern populations is not dependant upon delayed meristematic activity of terminal buds as might have been expected.

In general, factors that slow or stop growth also induce cold hardiness. The most important of these factors are decrease of temperature below a critical level and shortening of day length beyond a critical period. Dehardening involves a reversal of the direction of these factors (Alden and Hermann, 1971).

Bussell (1968) indicated that effects of photoperiod and temperature on the growth of several New Zealand tree species was quite different from that of the northern hemisphere species Acer pseudoplatanus. This species became dormant in short days and would not break dormancy with increasing temperature or daylength unless it had been subjected to a winter temperature below a specific minimum. The New Zealand trees required a combination of declining daylength and temperature to become dormant, but this dormancy was readily broken by increasing temperature in winter without any requirement for a preconditioning winter minimum temperature. However, Wardle and Campbell (1976) observed winter dormancy not immediately broken by raising temperature in New Zealand mountain beech (Nothofagus solandri var. cliffortioides) collected near the timber line.

Regulation by a plant of its growth activity in response to temperature changes and photoperiod is an effective response to reduce or avoid cold damage to tissue, both by the conditioning of a plant to withstand low winter temperatures and to delay bud break in spring when a growth response to rising temperature alone would make a plant susceptible to late frosts. The response pattern shown in figure 6 points to the dehardening of $L$ scoparium population in spring being affected by both temperature and photoperiod. It conforms to a hypothesis that the temperature threshold at which spring growth is activated decreases as latitude of origin increases, and that there might also be a photoperiodic influence which delays the onset of spring growth in montane populations compared to lower altitude populations at similar latitudes. Such photoperiodic control would be effective in reducing the possi- bility of damage to spring growth by frosts in a montane environment where frosts may occur well after there is no possibility of frost occurring in a locality of lower altitude, eg Lake Tekapo, figure $3 b$. However, the possibility that the delayed spring growth of the montane populations is regulated by a temperature threshold to avoid frost damage in the season when frost damage is more likely cannot be excluded.

In suggesting a photoperiodic influence on spring bud movement of $L$ scoparium it should be noted that seasonal change of day length at Angers is most similar to that at the locations of the most southern populations from New Zealand. Testing at a site with a very different day length pattern would most likely induce another pattern of growth response differences between populations.

\section{CONCLUSIONS}

Although controlled freezing experiments such as those conducted by Bannister (1986), Sakai and Wardle (1978) and Warrington and Stanley (1987) have been useful in indicating the limits of cold tolerance of $L$ scoparium, extrapolation of their results to plants growing in the soil outdoors is limited by the artificiality of the testing procedures they used. Plants when exposed to frost outdoors experience a gradient of temperatures from the top of the shoot to the bottom of the root zone. This gradient is further modified by canopy effects and the impact of the altered temperatures differs with the type and maturity of tissue. The difference between the extent of damage shown at Angers and Landerneau emphasises the importance of climatic conditions that precede damaging freezing temperatures. This points to the usefulness of site specific evaluations and to the limitations of extrapolating results obtained at one outdoor site to predict a response at another. A useful extension of the assessment of cold hardiness would be to apply the controlled frost testing technique used by Warrington and Stanley (1987), which was applied to a set of plants grown in different seasons, to a set of plants subjected to different hardening regimes in different localities or under controlled conditions.

Adaptation of plants to withstand freezing damage has two main components; the temperature a plant can tolerate before it shows damage, and regulation of the period during which the plant remains cold hardy. In environments 
where winter temperatures remain consistently below those allowing dehardening and growth, temperature controlled hardening and dormancy alone could provide an adequate response to avoid cold damage. It has been observed that some plants from extremely continental climates of Russia will grow in winter at Angers but are susceptible to cold damage (unpublished observations). In other environments temperatures during the frost season may vary to be high enough to allow growth or cause dehardening resulting in tissue susceptible to cold damage unless there are mechanisms to prevent this. Possible mechanisms are photoperiodic control, or a delay in the breaking of dormancy until after a period of temperatures that would otherwise allow growth has passed.

Latitudinal, altitudinal and coastal influences in New Zealand provide a range of winter environments in which there is a balance between the risk of $L$ scoparium suffering cold damage and the opportunity it has to grow and so compete more effectively with associated plants during the annual frost period. The results presented in figures 5 and 6 indicate that $L$ scoparium has adapted to this balance in different parts of its range and that this may involve both temperature and photoperiodic control of growth activity. Within population variation of response would allow a buffering of a population against seasonal variations of frost levels or competition induced by growth in the frost season.

The demonstration of significant variation in the resistance to damage by freezing in $L s c o$ parium points to the opportunity to combine the freezing tolerance shown by montane populations of this species and with the ornamentally desirable characteristics of flower colour and form, and shrub shape of cultivars which are not as cold hardy. This should increase the area in France and other parts of Europe where $L$ scoparium could be grown successfully as an ornamental.

Although the extreme of freezing tolerance of montane populations of $L$ scoparium when grown in the environment of Angers has yet to be tested, it remains likely that these populations would be killed by the occasional episodes of very cold temperatures that have been recorded for the locality. However, use of the cold tolerance of the montane populations would increase the number of years in which the species would be undamaged, receive minor damage or survive severe damage. Together with suitable shelter this could make the growing of the spe- cies as an ornamental in the regions more acceptable.

The comparison of temperature regimes of sites in New Zealand and France show that there is sufficient similarity between the colder zones of the South Island and those of the temperate regions of France to envisage increased use of New Zealand plants in horticulture in western Europe. In this regard, the region of Lake Tekapo appears to be most favourable for the natural selection of genotypes adapted to temperature regimes in western Europe. The occurrence in western Europe of occasional episodes of severe freezing of extended duration caused by the movement of continental air masses, is a situation that does not exist in New Zealand. Experiments are needed to test the response of New Zealand plants to this type of cold. Better understanding of the mechanisms of cold resistance, combined with some cycles of hybridization and selection, should enable the threshold of cold resistance to be raised. As well as temperature constraints, other factors such as soil permeability and acidity will need to be considered.

\section{ACKNOWLEDGMENTS}

The authors are grateful to Mrs D Percy for assisting in assembly of seed material, Mr E. Berninger and $\mathrm{Mr}$ Le Nard for maintenance of the plantings at Fréjus and Landerneau respectively, and Dr P Wardle for discussion on the subject of the study. Research by $W$ Harris in France was made possible by grants from INRA, CIES and the New Zealand DSIR.

\section{REFERENCES}

Alden J, Hermann RK (1971) Aspects of the cold hardiness mechanism in plants. Bot Rev 37(1), 37142

Allan HH (1961) Flora of New Zealand. Volume I. Indigenous Tracheophyta. Gov Printer, Wellington, New Zealand, 1085 pp

Bannister P (1986) Winter frost resistance of leaves of some plants grown in Dunedin, New Zealand, in winter 1985. NZ J Bot 24, 505-507

Bean WJ (1973) Trees and Shrubs Hardy in the British Isles. John Murray London, vol 2, 548-553

Bossard R, Cuisance P (1984) Arbres et Arbustes d'Ornement des Régions Tempérées et Méditerranéennes. Lavoisier, Paris, $600 \mathrm{pp}$

Bourgary A (1985) L'actualité météorologique. La vague de froid de Janvier 1985. Métérorol $7^{e}$ Sér, April 85, 38-42

Brooker SG, Cambie RC, Cooper RC (1988) Economic Native Plants of New Zealand. Botany Div, Christchurch, $130 \mathrm{pp}$ 
Bussell WT (1968) The growth of some New Zealand trees. 2. Effects of photoperiod and temperature. $N Z J$ Bot 6, 76-85

Connor HE (1985) Biosystematics of higher plants in New Zealand 1965-1984. N Z J Bot 23, 613-644

Cook JM, Mark AF, Shore BF (1980) Response of Leptospermum scoparium and $L$ ericoides (Myrtaceae) to waterlogging. $N Z J$ Bot 18, 233-246

Lammerts WE (1945) New double flowering Leptospermum hybrids. J Calif Hortic Soc 6(3), 250-257

Lee WG, Mark AF, Wilson JB (1983) Ecotypic differentiation in the ultramafic flora of the South Island, New Zealand. N Z J Bot 21, 141-156

Metcalf LJ (1987) The Cultivation of New Zealand Trees and Shrubs. Reed Methuen, Auckland, 346 $\mathrm{pp}$

New Zealand Meterological Service (1980) Summaries of climatological observation to 1980. NZ Meterol Serv Misc Public 177, 172 pp
Service Météorologique Métropolitain. Division Climatologie, Paris (1983) Normales Climatologiques 1951-1980. Fascicule 1 Températures. Données et Statistiques, No 4, $430 \mathrm{pp}$

Sakai A, Wardle P (1978) Freezing resistance of New Zealand trees and shrubs. $N Z J$ Ecology 1, 51-65

Thompson $J$ (1989) A revision of the genus Leptospermum (Myrtaceae). Telopea 3(3), 301-448

Wardle P, Campbell AD (1976) Winter dormancy in seedlings of mountain beech (Nothofagus solandri var cliffortioides) near timber line. $N Z J$ Bot 14 , 183-186

Warrington IJ, Stanley CJ (1987) Seasonal frost tolerance of some ornamental, indigenous New Zealand plant species of the genera Astelia, Dicksonia, Leptospermum, Metrosideros, Phormium, Pittosporum and Sophora. $N Z$ J Exp Agric 15, 357-366

Yin Ronghua, Mark AF, Wilson JB (1984) Aspects of the ecology of the indigenous shrub Leptospermum scoparium (Myrtaceae) in New Zealand. N Z J Bot 22, 483-507 